УДК $330.3(81)$

Alicia Maria Nervis Frigeri, student of the international faculty, Kursk State Medical University, Kursk, Russia

email:murilo_hideo1@hotmail.com

Murilo Hideo Nascimento Hayashi, student of the international faculty, Kursk State Medical University, Kursk, Russia

email:murilo_hideo1@hotmail.com

\title{
ECONOMIC DEVELOPMENT OF BRAZIL
}

Abstract: the article describes the trends of economic development of Brazil. Macroeconomic indicators such as Gross Domestic Product (GDP), Human Development Index (HDI) are studied. The main differences of economic development of regions are revealed. It was concluded that the economic diversity and GDP will determinate the quality life.

Key words: economic development, GDP, HDI, Brazil

Алисия Мария Нервис Фрижери, студент международного факультета, Курского Государственного Медицинского Университета электронная почта: murilo_hideo1@hotmail.com

Мурило Хидео Насимиенто, студент международного факультета, Курского Государственного Медицинского Университета электронная почта: murilo_hideo1@hotmail.com

\section{ЭКОНОМИЧЕСКОЕ РАЗВИТИЕ БРАЗИЛИИ}

Аннотация: в статье рассматриваются тенденции экономического развития Бразилии. Изучаются такие макроэкономические показатели, как валовой внутренний продукт (ВВП), индекс развития человеческого потенциала (ИРЧП). Выявлены основные отличия экономического развития регионов Бразилии. 
Сделан вывод о том, что качество жизни населения зависит от особенностей экономического развития и уровня ВВП.

Ключевые слова: экономическое развитие, ВВП, ИРЧП, Бразилия

Brazil is the $5^{\text {th }}$ largest in the world, with $8,515,767 \mathrm{~km}^{2}$ of territory, largest country in south America, and listed in $8^{\text {th }}$ biggest GDP by International Monetary Fund and World Bank, nominal GDP 2,054,969 US\$ million in 2017 and a population of 208,494 million [1,2]. Brazil have most of its size located in the equator, and the rest in below tropic of Capricorn, making its climate susceptible to agriculture. Nowadays the components of Brazil's GDP are $72.8 \%$ service sector, $21 \%$ industrial sector, and $6.2 \%$ agriculture, according to Index Mundi, divided in its 5 macroregions (North, Northeast, Central-West, Southeast, South) [3]. Each region has a different main economic component, and in this article will analyse the relation between the main component and Human Development Index (HDI). The figure below shows the breakdown of Brazil's sector GDP.

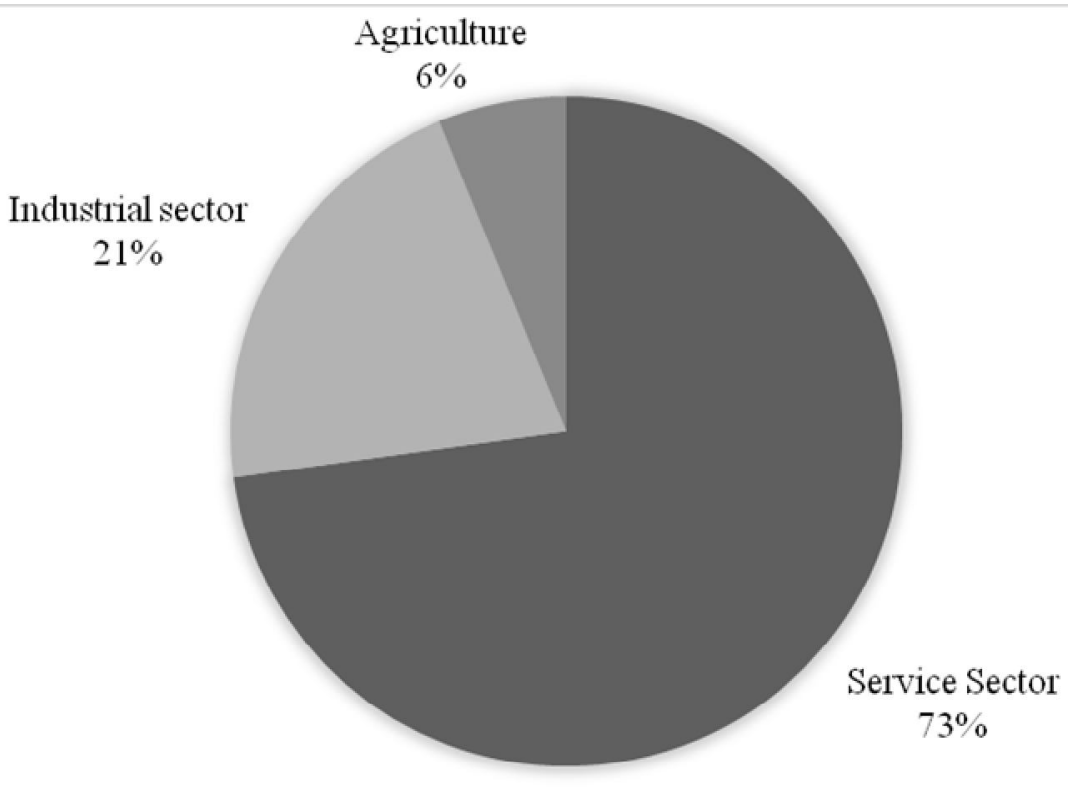

Figure 1 - Components of Brazil GDP in 2017

North Region is the largest region with 7 federation units, representing $45.27 \%$ of all country size, and is where is located the Amazon Forest, the largest tropical forest. Although it's the almost half of the country size, the North region GDP is the smallest, 
only 5,3\%[4]. That's because historically this region was occupied for extraction, and even today's it still the main economic activity. Extraction in this region includes, such as latex, açaí, woods and nuts; and mineral extraction of gold, precious stones, cassiterite and tin (metal); as well as mining exploitation, mainly iron, at Carajás Mountain Range (in the State of Pará) and manganese, at Navio Mountain Range (in the State of Amapá). Its HDI is $0,683\left(4^{\text {th }}\right)$ which will be looked if its reflex of economy based on the primary sector (extraction, and collection of natural sources) [5]. CentralWest Region is the $2^{\text {nd }}$ largest region with 3 federal units and a federal district. Even though this region is predominant urban, the primary sector is the main economic activity, agriculture, extraction and Animal husbandry. The industries are not much expressive when it comes to GDP. The industries that exist are fertilizers industries, animal feed, pharmaceutical and Hyundai Motor Company. The HDI is $0,753\left(2^{\text {nd }} / 3^{\text {rd }}\right)$ it has a higher HDI compared to North region and a relatively close economic activity, but it relies less in extraction [4,5]. Northeast Region was the historic base of Brazil, and was the spot of the first economic activity in Brazil, the extraction of Pau-Brazil, and sugar cane cultivation. It's the $3^{\text {rd }}$ place GDP among the regions, in 2011 the nominal GDP was R\$555,3 Billions, surpassing some country’s GDP, such as Chile, Singapore, and Portugal. And its economic activity is diversified, Industries, Services such as tourism, and transport. But is the lowest HDI of all regions with only $0,659 \quad\left(5^{\text {th }}\right)$ [4][5]. South region is the smallest among all the region, but with the highest HDI 0,756 the region has a variety of components in to its economy, all three sectors make up almost equally the GDP [4][5]. Southeast is the richest and most industrialized region of Brazil, being responsible for more than $70 \%$ industry value. And São Paulo city is the biggest and most important economic center and financial in the Latin America. Making up large portion of the service sector of Brazil GDP. The industries that have the most impacts are Oil, ship craft, automobile, steelworks, and petrochemistry [4]. And HDI 0,753 the same as Central-West [5]. 
ПОЛИТИКА, ЭКОНОМИКА И ИННОВАЦИИ № 2 (25), 2019

Table 1- GDP and HDI per region and the total GDP and median of HDI

\begin{tabular}{|l|l|l|}
\hline Region & GDP(Million,BRL) & HDI \\
\hline North & 320773 & 0,683 \\
\hline Central-West & 542632 & 0,753 \\
\hline Northeast & 722809 & 0,659 \\
\hline South & 672049 & 0,756 \\
\hline Southeast & 2295690 & 0,753 \\
\hline Total & 4553953 & 0,720 \\
\hline
\end{tabular}

Comparing the Southeast and West-Central IDH with the GDP of each region can't be conclude that the economic diversity or the nominal GDP will determinate the quality life. But also, it should be remembered that was only used the nominal GDP to comparison, it was included social and historical data that could justify this result.

\section{References}

1. Territorial area of Brazil //https://www.ibge.gov.br/cidades-e-estados.html

2. Brazil GDP//https://data.worldbank.org/country/brazil

3. Brazil GDP -Composition by sector //https://www.indexmundi.com/brazil/gdp_composition_by_sector.html

4. Brazil GDP per region //https://ww2.ibge.gov.br/home/estatistica/economia/contasregionais/2012/default_xls_2 002_2012.shtm

5. HDI per states in Brazil //http://www.atlasbrasil.org.br/2013/consulta/ 